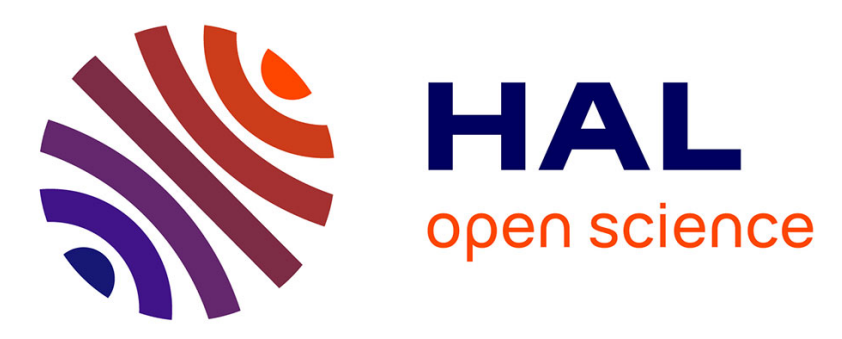

\title{
Energy utilization in pigs selected for high and low residual feed intake
}

Roberto Barea Gaitan, Serge Dubois, Hélène Gilbert, Pierre Sellier, Jaap J. van Milgen, Jean Noblet

\section{- To cite this version:}

Roberto Barea Gaitan, Serge Dubois, Hélène Gilbert, Pierre Sellier, Jaap J. van Milgen, et al.. Energy utilization in pigs selected for high and low residual feed intake. Journal of Animal Science, 2010, 88 (6), pp.2062-2072. 10.2527/jas.2009-2395 . hal-01193557

\section{HAL Id: hal-01193557 https://hal.science/hal-01193557}

Submitted on 31 May 2020

HAL is a multi-disciplinary open access archive for the deposit and dissemination of scientific research documents, whether they are published or not. The documents may come from teaching and research institutions in France or abroad, or from public or private research centers.
L'archive ouverte pluridisciplinaire HAL, est destinée au dépôt et à la diffusion de documents scientifiques de niveau recherche, publiés ou non, émanant des établissements d'enseignement et de recherche français ou étrangers, des laboratoires publics ou privés. 


\section{JOURNAL OF ANIMAL SCIENCE}

The Premier Journal and Leading Source of New Knowledge and Perspective in Animal Science

\section{Energy utilization in pigs selected for high and low residual feed intake}

R. Barea, S. Dubois, H. Gilbert, P. Sellier, J. van Milgen and J. Noblet

J ANIM SCI 2010, 88:2062-2072.

doi: 10.2527/jas.2009-2395 originally published online February 12, 2010

The online version of this article, along with updated information and services, is located on the World Wide Web at:

http://www.journalofanimalscience.org/content/88/6/2062 
References

Citations

This article cites 49 articles, 20 of which you can access for free at: http://www.journalofanimalscience.org/content/88/6/2062\#BIBL

This article has been cited by 14 HighWire-hosted articles:

http://www.journalofanimalscience.org/content/88/6/2062\#otherarticles 


\title{
Energy utilization in pigs selected for high and low residual feed intake ${ }^{1}$
}

\author{
R. Barea, ${ }^{*}+\dagger^{2}$ S. Dubois, ${ }^{*} \dagger$ H. Gilbert,§\# P. Sellier,§\# J. van Milgen, ${ }^{*} \dagger$ and J. Noblet $\dagger^{*}$ \\ *INRA, UMR1079 Systèmes d'Elevage, Nutrition Animale et Humaine (SENAH), F-35590 Saint-Gilles, France; \\ $\dagger$ Agrocampus Ouest, UMR1079 SENAH, F-35000 Rennes, France; $\ddagger$ Institute of Animal Nutrition, \\ Estación Experimental del Zaidín, Consejo Superior de Investigaciones Científicas (CSIC), Cno. del Jueves s/n, \\ 18100 Armilla, Granada, Spain; §INRA, UMR 1313 Génétique Animale et Biologie Intégrative (GABI), \\ F-78352 Jouy-en-Josas, France; and \#AgroParisTech, UMR1313 GABI, F-75231 Paris, France
}

\begin{abstract}
Genetic selection on residual feed intake (RFI) can be used as an alternative method to G:F to improve feed efficiency in pigs. The objective of this study was to determine the effects of selection for RFI on digestive and metabolic utilization of energy in 2 lines of purebred French Large White castrated male pigs obtained from a divergent selection experiment over 6 generations. The $\mathrm{RFI}^{+}$(high RFI) line consumed more feed than predicted from performance compared with the $\mathrm{RFI}^{-}$(low RFI) line. Digestibility of energy and nutrients, total heat production (HP), $\mathrm{HP}$ related to physical activity, and energy and $\mathrm{N}$ balance were measured in respiration chambers for a 6 -d period in pigs offered feed ad libitum. Pigs remained in the chamber for an additional day and did not receive any feed to estimate the fasting HP and calculate the thermic effect of feeding. Five pairs of 2 littermates from the same farrowing batch were used in each line. Because 2 respiration chambers were available for the trial, pigs were measured regularly during the 25- to 95-kg growing period. Two pigs per chamber were used until pigs reached $45 \mathrm{~kg}$ of $\mathrm{BW}$, and 1 pig per chamber was used thereafter. Individual feed intake and BW gain were measured continuously from weaning to the
\end{abstract}

end of the trial. Pigs were fed 3 diets with decreasing CP contents during the 25 to 45 (period 1), 45 to 65 (period 2), and 65 to 95 (period 3) kg of BW periods. Average daily feed intake was greater in $\mathrm{RFI}^{+}$pigs than in $\mathrm{RFI}^{-}$pigs between 25 and $65 \mathrm{~kg}$ of BW (2,128 vs. $1,891 \mathrm{~g} / \mathrm{d} ; P<0.01)$ and $\mathrm{G}: \mathrm{F}$ was $8 \%$ greater in $\mathrm{RFI}^{-}$ pigs compared with $\mathrm{RFI}^{+}$pigs $(P<0.01)$. There was no line effect on digestibility coefficients or $\mathrm{N}$ retention, irrespective of the experimental period studied. Nitrogen retention was $31.2,28.7$, and $20.8 \mathrm{~g} / \mathrm{d}$ at periods 1 , 2 , and 3 , respectively $(P<0.001)$. The HP was greater in $\mathrm{RFI}^{+}$pigs than in $\mathrm{RFI}^{-}$pigs $(1,497$ vs. $1,383 \mathrm{~kJ} \cdot \mathrm{kg}$ of $\left.\mathrm{BW}^{-0.60} \cdot \mathrm{d}^{-1} ; P<0.01\right)$, with no subsequent line effect on energy retention. The activity-related HP tended to be greater in $\mathrm{RFI}^{+}$pigs than in $\mathrm{RFI}^{-}$pigs (250 vs. 218 $\mathrm{kJ} \cdot \mathrm{kg}$ of $\left.\mathrm{BW}^{-0.60} \cdot \mathrm{d}^{-1} ; P=0.09\right)$, and the fasting $\mathrm{HP}$ was $10 \%$ greater $(P=0.04)$ in $\mathrm{RFI}^{+}$pigs than in $\mathrm{RFI}^{-}$pigs (846 vs. $771 \mathrm{~kJ} \cdot \mathrm{kg}$ of $\left.\mathrm{BW}^{-0.60} \cdot \mathrm{d}^{-1}\right)$. The thermic effect of feeding, expressed as a percentage of ME intake, was the same for both lines of pigs (average, 14.7\%). In conclusion, the $\mathrm{RFI}^{+}$pigs are energetically less efficient because of their greater HP related to physical activity and basal metabolic rate.

Key words: energy utilization, fasting heat production, growing pig, heat production, residual feed intake

(C)2010 American Society of Animal Science. All rights reserved.

J. Anim. Sci. 2010. 88:2062-2072

doi:10.2527/jas.2009-2395

\section{INTRODUCTION}

Improving feed efficiency is one of the major objectives of current animal breeding to reduce feed costs and enhance the availability of plant resources for other purposes. Estimated during the growing period, the residual feed intake (RFI) is defined as the difference between the actual feed intake of an animal and that theoretically required for maintenance and growth (Gilbert et al., 2007). The RFI has been proposed as an alternative to G:F to measure feed efficiency in cattle (Arthur et al., 2001; Nkrumah et al., 2007), laying hens 
(Bordas and Mérat, 1981; Luiting and Urff, 1991), pigs (Gilbert et al., 2007; Cai et al., 2008), and fish (Silverstein et al., 2005; Grima et al., 2008).

The variation in RFI reflects differences in digestion processes, metabolic utilization of feed intake, or both in animals of similar BW and production levels (Nguyen et al., 2005). In cattle, RFI has been positively correlated with $\mathrm{CH}_{4}$ emissions and heat production (HP) or retained energy (RE), but not with maintenance energy requirements $\left(\mathbf{M E}_{\mathbf{m}}\right)$ or efficiency of utilization of ME for growth (Nkrumah et al., 2006; Castro Bulle et al., 2007). Luiting et al. (1991) suggested that up to $85 \%$ of the difference in HP between lines of hens differing in RFI can be related to differences in physical activity. In contrast, data concerning genetic variation in feed digestibility and partitioning of $\mathrm{ME}$ related to differences in RFI do not exist for growing pigs.

The purpose of the current study was to estimate the relationship between RFI and digestibility coefficients and energy partitioning (i.e., HP, physical activity, and basal metabolic rate) in growing pigs, using digestibility and balance trials combined with HP measurements in respiration chambers in 2 divergent Large White lines selected for high $\left(\mathbf{R F I}^{+}\right)$or low $\left(\mathbf{R F I}^{-}\right) \mathrm{RFI}$ and differing significantly in that trait (Gilbert et al., 2007).

\section{MATERIALS AND METHODS}

The study was conducted in accordance with the French legislation on animal experimentation and ethics, and the senior researchers are authorized by the French Ministry of Agriculture to conduct experiments on living animals at the INRA facilities in Saint-Gilles, France.

\section{Animals and Experimental Design}

The aim of this study was to investigate to what extent differences in nutrient digestion and energy partitioning contribute to differences in RFI. In this study, 2 lines of purebred French Large White castrated male pigs with differences in RFI but showing similar growth rate and body composition were used. The $\mathrm{RFI}^{+}$or $\mathrm{RFI}^{-}$lines had, respectively, a greater or reduced feed consumption relative to the feed intake predicted from their performance. However, over successive generations, there has been a tendency for greater growth rate and body fatness in the $\mathrm{RFI}^{+}$line (Gilbert et al., 2007; Sellier et al., 2010). The experimental animals were obtained from a divergent selection experiment for RFI, which was begun at INRA in 2000. The design of the selection program and the estimates of genetic parameters over the first 4 generations of selection have been described by Gilbert et al. (2007). Animals used in the current study belonged to the sixth generation of selection. In generation 6 , the line difference amounted to 2.8 genetic SD units of the selection criteria recorded on selected males (Sellier et al., 2010).
At weaning (i.e., at approximately 4 wk of age), castrated male piglets were transported from the selection herd (INRA-Génétique et Expérimentation en Productions Animales, Le Magneraud, France) to the laboratory in Saint-Gilles (INRA, France) for balance tests, which consisted of 6-d trials, during which the $\mathrm{N}$, energy (through indirect calorimetry), and $\mathrm{P}$ balances were determined in pigs offered feed ad libitum. These balance tests were followed by 1 fasting day to estimate the fasting HP (FHP). In each line, experimental animals consisted of 5 pairs of 2 littermates from 5 sows sired by 4 or 5 different boars. A total of 20 animals were therefore used in the trial, and trials began at an initial BW of approximately $25 \mathrm{~kg}$. Because only 2 large respiration chambers were available, 2 balance tests were performed each week, using 2 littermate pigs per chamber, until the pigs weighed 40 to $45 \mathrm{~kg}$, after which 1 pig per chamber was used for heavier pigs. The total experimental period was divided in 3 periods ( $\mathbf{P 1 :}$ 25 to $45 \mathrm{~kg}$ of BW; P2: 45 to $65 \mathrm{~kg}$ of BW; and P3: 65 to $95 \mathrm{~kg}$ of BW). Because of a decrease in AA requirements relative to $\mathrm{BW}$, the $\mathrm{CP}$ content was decreased over successive periods. In practice, 4 pairs of pigs were tested at each period, whereas pigs in the last pair were considered as possible substitutes. Similarly, after 40 to $45 \mathrm{~kg}$ of BW, the remaining pig within each pair was considered a possible substitute. In addition, 1 pair of pigs measured at P2 was not systematically measured at P3. Therefore, the overall design could not be considered a repeated measures design.

Genetic values of the 20 pigs used in the balance trials were estimated based on individual feed intake of 1,065 controlled pigs of generations 0 to 6 , using the REML methodology (Patterson and Thompson, 1971) applied to a multitrait individual animal model (Gilbert et al., 2007). Average differences in genetic values for pigs sampled for the present study from the $\mathrm{RFI}^{+}$line and the $\mathrm{RFI}^{-}$line were very close to those estimated for the contemporary group of generation 6 for growth and feed intake traits (Sellier et al., 2010). The differences were 21.1 points for the selection index (compared with 21.0 points for the contemporary group), $229 \mathrm{~g}$ for ADFI (compared with $225 \mathrm{~g}$ ), $14 \mathrm{~g}$ for ADG (compared with $19 \mathrm{~g}$ ), and 0.27 for G:F (compared with 0.23 ).

\section{Housing and Feeding}

Pigs were offered commercial weaner and starter diets ad libitum until reaching $25 \mathrm{~kg}$ of BW. The starter diet was then progressively replaced (over $3 \mathrm{~d}$ ) by the diet used in P1. All diets were formulated on an asfed basis and were based on a corn, wheat, and barley mixture and soybean meal (Table 1). The supply of AA met or exceeded the current French recommendations, expressed on a standardized ileal digestible AA basis (Henry, 1993; Sève and Le Floc'h, 1998). Other nutrients and energy content were formulated to meet or exceed the requirements of pigs for the experimental 
periods studied. During the energy balance measurements, feed and water were offered ad libitum. To control the variation in feed intake between littermates, pigs within a litter were offered the same quantity of feed, which was slightly below their ad libitum intake capacity, between the balance trial periods. During the experiment, pigs were housed in pens (with 2 pigs per pen) until reaching 30 to $35 \mathrm{~kg}$ of BW and were housed in individual metabolism cages thereafter. During the balance trials, pigs were housed in one of the two 12$\mathrm{m}^{3}$ open-circuit respiration chambers based on a design similar to that used by Vermorel et al. (1973). In the respiration chamber, animals remained in their pens or metabolism cages, which were mounted on force sensors (Type 910A, Kistler, Winterthur, Switzerland). These sensors produce an electrical signal to measure the physical activity of the pigs. In each respiration chamber, feeders were placed on a load cell to continuously measure feed intake and traits of feeding behavior (i.e., time, size, and duration of each meal) through changes in trough weights (van Milgen et al., 1997). Only results for total daily feed intake are presented. The respiration chambers were climate controlled to maintain a constant temperature and relative humidity $\left(24^{\circ} \mathrm{C}\right.$ and $70 \%$, respectively) during the balance trials. A 12-h lighting time span (from 0800 to $2000 \mathrm{~h}$ ) was used.

\section{Measurements}

Pigs were weighed after an overnight fast at the beginning and at the end of $\mathrm{P} 1, \mathrm{P} 2$, and $\mathrm{P} 3$ to determine their ADG. Feed intake was measured each week, taking into account possible feed refusals or spillage. During the balance trials, pigs were weighed when they were moved into the respiration chamber before the morning meal and on the mornings before and after the fasting day. Feed refusals (if any) were collected daily, weighed, and then subjected to DM determination. Feed samples were taken at the time of diet preparation and were pooled for each balance trial for immediate DM determination and further analyses.

Feces and urine (the latter in a container with $\mathrm{H}_{2} \mathrm{SO}_{4}$ ) were collected separately each day per pig (or per 2 pigs in P1) during the 6-d period and stored at $2^{\circ} \mathrm{C}$. Subsequently, pooled fecal and urine samples (d 1 to 6 per pig or groups of 2 pigs in P1) were weighed, mixed, subsampled, and freeze-dried for chemical analyses. A second sample of homogenized feces was obtained to estimate the $\mathrm{DM}$ content by desiccation at $103^{\circ} \mathrm{C}$ for $48 \mathrm{~h}$.

In the respiration chamber, gas concentrations (i.e., $\mathrm{CO}_{2}, \mathrm{O}_{2}$, and $\mathrm{CH}_{4}$ ) of outgoing air and the ventilation rate were measured continuously according to the methods described by van Milgen et al. (1997). The $\mathrm{O}_{2}$ concentration was measured with a paramagnetic differential analyzer (Oxymat 6, Siemens AG, Munich, Germany), whereas infrared analyzers were used to measure the concentrations of $\mathrm{CO}_{2}$ (Ultramat 6 , Siemens
AG or Unor 600, Maihak AG, Hamburg, Germany) and $\mathrm{CH}_{4}$ (Unor $6 \mathrm{~N}$, Maihak AG). Because only $1 \mathrm{CH}_{4}$ analyzer was available for the 2 respiration chambers, the $\mathrm{CH}_{4}$ concentration was measured using an alternating scheme of $3 \mathrm{~d}$ of measurement per chamber. Gas extraction rate was measured by a mass gas flow meter (Hasting Teledyne Brown Engineering, Hampton, VA). Gas concentrations, the signals of the force sensors, the weight of pig feeders, gas flow rate, and physical conditions in the chamber (i.e., temperature, humidity, and barometric pressure) were measured 60 times/s, averaged over 10-s intervals, and averages were recorded for further calculations. Ammonia losses recovered in condensed water and outgoing air were collected according to the methods described by Noblet et al. (1987).

\section{Chemical Analyses}

The DM content of representative feed samples, feces, and feed refusals was determined according to AOAC (1990) methods. Samples of feed, feces, urine (as fresh material), condensed water, and extracted air were analyzed for $\mathrm{N}$ according to the Dumas procedure (Leco 3000, Leco Corporation, St. Joseph, MI). In addition, ash, $\mathrm{P}$ (spectrophotometric method: ashing at $550^{\circ} \mathrm{C}$ and dissolving in $16 \mathrm{~N} \mathrm{HNO}_{3}$ ), and GE (IKA C5000, IKA, Staufen, Germany) contents in feces and feed samples were determined. For urine, the GE content was determined after freeze-drying approximately $30 \mathrm{~mL}$ of urine in polyethylene bags. The $\mathrm{P}$ content of urine was also determined. Finally, feed samples were analyzed for ether extract (Soxtec Avanti 2050; Foss, Höganäs, Sweden), starch (the Ewers polarimetric method; European Economic Community, 1972), Weende crude fiber, NDF, ADF (Ankom 2000 Fiber Analyzer, Ankom Technology, Macedon, NY), and ADL (Van Soest and Wine, 1967).

\section{Calculations}

For calculations, all data were expressed per pig and per day, even in the early periods with 2 pigs per respiration chamber (i.e., average of the 2 pigs). For the periods during which pigs were housed in pairs (i.e., until reaching 40 to $45 \mathrm{~kg}$ of $\mathrm{BW}$ ), the individual feed intake for calculating the growth performance over P1 and the total trial was estimated by dividing ADG of each pig by the G:F measured in the 2 pigs. Nitrogen retention (NR) was calculated as the difference between $\mathrm{N}$ intake and $\mathrm{N}$ losses in feces, urine, condensed water, and extracted air. The $\mathrm{P}$ retention was calculated as the difference between $\mathrm{P}$ intake and $\mathrm{P}$ losses in feces and urine. The DE and ME values of the diet were calculated according to the methods described by Noblet et al. (1987). The $\mathrm{CH}_{4}$ production, expressed as a percentage of DE intake over a part of the balance period, was small and rather variable between successive days for a given animal and between animals. Therefore, in the calculation of ME, the overall mean 
Table 1. Ingredients and chemical composition of the diets (as-fed basis)

\begin{tabular}{|c|c|c|c|}
\hline \multirow[b]{2}{*}{ Item } & \multicolumn{3}{|c|}{ Experimental period ${ }^{1}$} \\
\hline & $\mathrm{P} 1$ & $\mathrm{P} 2$ & P3 \\
\hline \multicolumn{4}{|l|}{ Ingredient, $\%$} \\
\hline Corn & 23.48 & 25.39 & 30.15 \\
\hline Wheat & 23.00 & 23.00 & 22.40 \\
\hline Barley & 23.00 & 23.00 & 21.60 \\
\hline Soybean meal & 21.70 & 18.70 & 16.30 \\
\hline Sunflower oil & 0.50 & 0.00 & 0.00 \\
\hline Molasses & 2.00 & 2.00 & 2.00 \\
\hline Wheat bran & 3.00 & 5.00 & 5.00 \\
\hline Dicalcium phosphate & 1.30 & 1.10 & 0.90 \\
\hline Calcium carbonate & 0.80 & 0.70 & 0.60 \\
\hline Salt & 0.40 & 0.40 & 0.40 \\
\hline L-Lysine·HCl & 0.220 & 0.180 & 0.140 \\
\hline DL-Methionine & 0.040 & 0.000 & 0.000 \\
\hline L-Threonine & 0.060 & 0.030 & 0.010 \\
\hline l-Tryptophan & 0.005 & 0.000 & 0.000 \\
\hline Vitamin-mineral premix ${ }^{2}$ & 0.500 & 0.500 & 0.500 \\
\hline \multicolumn{4}{|c|}{ Analyzed chemical composition, ${ }^{3} \%$} \\
\hline $\mathrm{CP}$ & 17.7 & 16.1 & 15.7 \\
\hline Ash & 5.22 & 4.83 & 4.54 \\
\hline Ether extract & 2.4 & 1.8 & 2.2 \\
\hline $\mathrm{GE}, \mathrm{kJ} / \mathrm{g}$ & 16.03 & 15.97 & 16.06 \\
\hline Crude fiber & 3.2 & 3.3 & 3.3 \\
\hline NDF & 12.3 & 11.8 & 11.9 \\
\hline $\mathrm{ADF}$ & 4.1 & 3.9 & 4.4 \\
\hline $\mathrm{ADL}$ & 0.23 & 0.19 & 0.63 \\
\hline Starch & 42.1 & 44.3 & 45.2 \\
\hline $\mathrm{Ca}$ & 0.92 & 0.82 & 0.72 \\
\hline $\mathrm{P}$ & 0.66 & 0.63 & 0.57 \\
\hline \multicolumn{4}{|l|}{ Nutritional value, ${ }^{3}$} \\
\hline $\mathrm{ME},{ }^{4} \mathrm{~kJ} / \mathrm{g}$ & 12.79 & 12.64 & 12.71 \\
\hline $\mathrm{NE},{ }^{4} \mathrm{~kJ} / \mathrm{g}$ & 9.48 & 9.41 & 9.54 \\
\hline \multicolumn{4}{|l|}{ Digestible $\mathrm{AA}^{5}$} \\
\hline Lys, $\%$ & 0.90 & 0.81 & 0.72 \\
\hline Met + Cys, $\%$ & 0.56 & 0.50 & 0.48 \\
\hline Thr, $\%$ & 0.59 & 0.52 & 0.47 \\
\hline $\operatorname{Trp}, \%$ & 0.18 & 0.17 & 0.15 \\
\hline (Met + Cys):Lys & 62 & 62 & 67 \\
\hline Thr:Lys & 65 & 65 & 66 \\
\hline Trp:Lys & 20 & 21 & 21 \\
\hline
\end{tabular}

${ }^{1} \mathrm{P} 1=25$ to $45 \mathrm{~kg}$ of $\mathrm{BW} ; \mathrm{P} 2=45$ to $65 \mathrm{~kg}$ of BW; $\mathrm{P} 3=65$ to $95 \mathrm{~kg}$ of BW.

${ }^{2}$ Supplied per kilogram (as-fed basis) of diet: vitamin A, 5,000 IU; vitamin $\mathrm{D}_{3}, 1,000 \mathrm{IU}$; vitamin E, $20 \mathrm{IU}$; menadione, $2 \mathrm{mg}$; thiamine, $2 \mathrm{mg}$; riboflavin, $4 \mathrm{mg}$; niacin, $15 \mathrm{mg}$; pantothenic acid, $10 \mathrm{mg}$; pyridoxine, $1 \mathrm{mg}$; biotin, $0.2 \mathrm{mg}$; folic acid, $1 \mathrm{mg}$; cyanocobalamin, $0.02 \mathrm{mg}$; choline chloride, $500 \mathrm{mg}$; Fe, $80 \mathrm{mg}$ as ferrous carbonate; $\mathrm{Cu}, 10 \mathrm{mg}$ as copper sulfate; $\mathrm{Zn}, 100 \mathrm{mg}$ as zinc oxide; $\mathrm{Mn}, 37 \mathrm{mg}$ as manganous oxide; I, $0.2 \mathrm{mg}$ as calcium iodate; Se, $0.2 \mathrm{mg}$ as sodium selenite; and $\mathrm{Co}, 0.1 \mathrm{mg}$ as cobalt sulfate.

${ }^{3}$ Adjusted for $87.3 \%$ of DM.

${ }^{4}$ Values for ME and NE were calculated according to the method of Sauvant et al. (2004).

${ }^{5}$ Standardized ileal digestible AA, calculated from the digestibility of feed ingredients (Sauvant et al., 2004).

of methane energy loss during the trial was used for all animals. The first day in the respiration chamber was considered an adaptation day and was not included in the final calculations. Total HP was calculated from $\mathrm{O}_{2}$ consumption and $\mathrm{CO}_{2}$ production according to the equation of Brouwer (1965), which included average $\mathrm{CH}_{4}$ production and urinary $\mathrm{N}$ excretion. Energy retention was calculated as the difference between $\mathrm{ME}$ intake and HP over the measurement period. Assuming an energy value of protein gain of $23.6 \mathrm{~kJ} / \mathrm{g}$, energy retained as protein $\left(\mathbf{R E}_{\mathbf{p}}\right)$ was calculated from the $\mathrm{N}$ balance. Energy retained as fat $\left(\mathbf{R E}_{\mathrm{f}}\right)$ was calculated as the difference between total $\mathrm{RE}$ and $\mathrm{RE}_{\mathrm{p}}$. The $\mathrm{RQ}$ corresponds to the ratio between $\mathrm{CO}_{2}$ production and $\mathrm{O}_{2}$ consumption.

Simultaneous measurements of $\mathrm{O}_{2}$ and $\mathrm{CO}_{2}$ concentrations, physical activity (i.e., the signal of force sensors), and feeding behavior (i.e., the signal of load cells) in the respiration chamber, and physical characteristics of gas exchanges in the chamber were used as inputs to calculate the components of HP according to the modeling approach described by van Milgen et al. (1997). Briefly, the variations in $\mathrm{O}_{2}$ and $\mathrm{CO}_{2}$ concentrations in the chamber were related to $\mathrm{O}_{2}$ consumption and $\mathrm{CO}_{2}$ 
production by the pig. Actually, during periods when the pigs were fed, the model provided estimates of gas exchanges attributable to resting state, physical activity, and short-term thermic effect of feeding (TEF). During the fasting day, it provides estimates of gas exchanges attributable to fasting and physical activity during fasting. The ACSL/Optimize program (AEgis Simulation, AEgis Technologies, Huntsville, AL) was used to obtain estimates of model parameters describing gas exchanges. Components of total HP related to physical activity (AHP), feed intake (short-term TEF), and resting metabolism (resting HP) were calculated from these model parameters using only the estimated $\mathrm{O}_{2}$ consumption and $\mathrm{CO}_{2}$ production (Brouwer, 1965). The FHP was obtained from gas exchanges measured during the fasting day. The difference between resting HP and FHP was considered to correspond to the longterm TEF, whereas the sum of the long-term TEF and short-term TEF corresponded to the total TEF. All energy traits were calculated on a daily basis and further expressed relative to $\mathrm{BW}^{0.60}$ (Noblet et al., 1999).

\section{Statistical Analyses}

Data were subjected to ANOVA using the GLM procedure (SAS Inst. Inc., Cary, NC), and the individual pig (or the pair of pigs in P1) was used as the experimental unit for all data. The effects included in the ANOVA model were line, growing period, and their interaction. Least squares means for the effects were computed (LSMEANS statement in the GLM procedure) and the differences between the effects of levels were tested with a Student $t$-test (PDIFF option in the LSMEANS statement). The performance and energy balance results were also analyzed by covariance to refine the analysis of the overall treatment difference. The initial BW (i.e., BW at the beginning of the period) and ADG over the period were then included as covariates for data on, for instance, feed intake. Adjustment for a similar energy intake or RE as a covariate was also included in the energy balance data. The $\mathrm{ME}_{\mathrm{m}}$ was estimated according to the model proposed by Kielanowski (1965): $\mathrm{ME}=\mathrm{ME}_{\mathrm{m}}+\mathrm{RE}_{\mathrm{p}} / \mathrm{k}_{\mathrm{p}}+\mathrm{RE}_{\mathrm{f}} / \mathrm{k}_{\mathrm{f}}$. In this model, we assumed that the $\mathrm{ME}_{\mathrm{m}}$ requirement varied with $\mathrm{BW}$ (i.e., $\mathrm{ME}_{\mathrm{m}}=\mathrm{a}_{\mathrm{i}} \mathrm{BW}^{0.60}$ ), assuming a potentially different $a_{i}$ for each line of pigs; the values of $k_{p}$ and $k_{f}$ are supposed to be identical for both lines. This model allows the estimation of the partial efficiencies of using ME for protein and fat deposition (i.e., $\mathrm{k}_{\mathrm{p}}$ and $\mathrm{k}_{\mathrm{f}}$, respectively) and the effect of line on $\mathrm{ME}_{\mathrm{m}}$ (i.e., $\mathrm{a}_{\mathrm{i}}$ ). Differences were considered significant at $P<0.05$.

\section{RESULTS}

Throughout the experiment, pigs appeared to be healthy. However, we observed that feed intake ceased to increase as pigs reached 70 to $80 \mathrm{~kg}$ of BW and that feed intake was even reduced in some pigs. These reductions were often associated with appearance of leg problems, probably related to the prolonged stay in metabolism cages, which limited their physical activity. For this reason, 4 pigs ( 2 in each line) were removed from the study after $70 \mathrm{~kg}$ of $\mathrm{BW}$ and the others were progressively removed after being measured for the P3 stage. Growth performance data were thus available for all the animals up to approximately $70 \mathrm{~kg}$ of BW. Table 2 shows growth performance data for the immediate postweaning period (from 8.5 to $24.3 \mathrm{~kg}$ of $\mathrm{BW}$ ) and the growing period (from 24.3 to $67.7 \mathrm{~kg}$ of BW). During the immediate postweaning period, growth performance was affected by the line of pigs, with a greater ADFI (692 vs. $529 \mathrm{~g} / \mathrm{d} ; P<0.01)$ and a greater ADG (452 vs. $366 \mathrm{~g} / \mathrm{d} ; P=0.01$ ) in $\mathrm{RFI}^{+}$pigs. As expected, the G:F was less in the $\mathrm{RFI}^{+}$line. During the growing period, ADFI was also greater and G:F was less in $\mathrm{RFI}^{+}$pigs than in $\mathrm{RFI}^{-}$pigs $(P<0.01)$. In contrast, ADG was not affected by the pig line. Because of the reduced ADG during the immediate postweaning period, $\mathrm{RFI}^{-}$pigs were lighter at the beginning of the growing period. Adjustment of ADFI and G:F for initial BW emphasizes the reduced feed efficiency of the $\mathrm{RFI}^{+}$pigs $(P=0.04)$.

Table 3 shows the results of the balance trials and the effect of the pig line and growth period on nutrient and energy digestibility and on $\mathrm{N}$ and $\mathrm{P}$ balances. There was no interaction between line and growth period for any trait. Both ADFI and ADG tended to be greater in $\mathrm{RFI}^{+}$pigs than in $\mathrm{RFI}^{-}$pigs during the balance periods $(184 \mathrm{~g} / \mathrm{d}$ for ADFI and $159 \mathrm{~g} / \mathrm{d}$ for ADG; $P \leq 0.10)$. As expected, ADFI increased with increasing BW (1,752 to $2,456 \mathrm{~g} / \mathrm{d}$ from $\mathrm{P} 1$ to $\mathrm{P} 3$, respectively; $P<0.001$ ), but the increase between P2 and P3 was negligible. Digestibility coefficients of nutrients or energy were not affected by the pig line. Smaller digestibility coefficients for DM $(P<0.05)$, ash $(P<0.001)$, and $\mathrm{P}(P<0.01)$ were observed in P3 $(86.2,52.4$, and $50.1 \%$, respectively) compared with the other 2 periods (averaging 87.2, 61.0 , and $60.8 \%$, respectively). The digestibility coefficient of $\mathrm{N}$ was greater in $\mathrm{P} 2$ than in $\mathrm{P} 1(P<0.05)$ and was intermediary in P3. The digestibility coefficient of energy was not affected by line or growth period. The differences in digestibility coefficients between the periods must be interpreted with caution because diets were slightly different, with less CP and more starch in diets fed to the heavier pigs. Similarly to the digestibility coefficients, the energy utilization of DE (expressed as ME:DE) and energy values of the diets (ME and $\mathrm{NE}$ in $\mathrm{MJ} / \mathrm{kg}$ of $\mathrm{DM}$ ) were affected by the period, but not by the pig line. In agreement with the ADG, the N balance results confirmed the reduction $(P<0.001)$ in NR in P3 $(20.8 \mathrm{~g} / \mathrm{d})$ compared with those in P1 (31.2 $\mathrm{g} / \mathrm{d})$ and P2 $(28.7 \mathrm{~g} / \mathrm{d})$. The NR did not differ between the pig lines. Unlike the NR, the $\mathrm{P}$ retention was less in P1 and P3 (5.5 and $5.2 \mathrm{~g} / \mathrm{d}$, respectively) compared with P2 $(7.1 \mathrm{~g} / \mathrm{d})$. In addition, $\mathrm{P}$ retention was greater in $\mathrm{RFI}^{+}$pigs than in $\mathrm{RFI}^{-}$pigs $(6.2$ vs. $5.6 \mathrm{~g} / \mathrm{d} ; P<$ $0.05)$, but, when expressed per kilogram of BW gain, it was not different between lines $(P=0.44)$. 
Table 2. Effects of line on growth performance of pigs during the immediate postweaning (1- to 6-wk) and growing (6- to 12-wk) periods (least squares means; 4 observations per line and per period)

\begin{tabular}{|c|c|c|c|c|}
\hline \multirow[b]{2}{*}{ Item } & \multicolumn{2}{|c|}{ Line $^{1}$} & \multirow[b]{2}{*}{$\mathrm{RSD}^{2}$} & \multirow[b]{2}{*}{$P$-value ${ }^{3}$} \\
\hline & $\mathrm{RFI}^{+}$ & $\mathrm{RFI}^{-}$ & & \\
\hline \multicolumn{5}{|c|}{ Immediate postweaning period } \\
\hline Initial BW, kg & 8.81 & 8.17 & 1.17 & 0.24 \\
\hline Final BW, kg & 26.3 & 22.4 & 2.6 & $<0.01$ \\
\hline Duration, $\mathrm{d}$ & 38.8 & 39.0 & 0.3 & 0.15 \\
\hline $\mathrm{ADFI},{ }^{4} \mathrm{~g} / \mathrm{d}$ & 692 & 529 & 101 & $<0.01$ \\
\hline $\mathrm{ADG}, \mathrm{g} / \mathrm{d}$ & 452 & 366 & 69 & 0.01 \\
\hline $\mathrm{G}: \mathrm{F}^{4}$ & 0.654 & 0.689 & 0.026 & $<0.01$ \\
\hline \multicolumn{5}{|l|}{ Growing period ${ }^{5}$} \\
\hline Initial BW, kg & 26.3 & 22.4 & 2.6 & $<0.01$ \\
\hline Final BW, kg & 70.5 & 64.9 & 4.0 & $<0.01$ \\
\hline Duration, d & 47.9 & 47.9 & - & - \\
\hline $\mathrm{ADFI},{ }^{4} \mathrm{~g} / \mathrm{d}$ & 2,128 & 1,891 & 134 & $<0.01$ \\
\hline Adjusted ADFI, ${ }^{4,6} \mathrm{~g} / \mathrm{d}$ & 2,060 & 1,960 & 75 & 0.03 \\
\hline $\mathrm{ADG}, \mathrm{g} / \mathrm{d}$ & 923 & 888 & 56 & 0.18 \\
\hline $\mathrm{G}: \mathrm{F}^{4}$ & 0.435 & 0.469 & 0.020 & $<0.001$ \\
\hline Adjusted G:F $\mathrm{F}^{4,6}$ & 0.441 & 0.463 & 0.017 & 0.04 \\
\hline \multicolumn{5}{|c|}{$\begin{array}{l}{ }^{1} \mathrm{RFI}^{+}=\text {high residual feed intake; } \mathrm{RFI}^{-}=\text {low residual feed intake. } \\
{ }^{2} \mathrm{RSD}=\text { residual } \mathrm{SD}(18 \mathrm{df}) \text {, which is the root mean square of the error that applies to the whole model. } \\
{ }^{3} \mathrm{Effect} \text { of line. } \\
{ }^{4} \text { Adjusted for } 87.3 \% \text { of } \mathrm{DM} \text {. } \\
{ }^{5} \text { Approximately from } 25 \text { to } 70 \mathrm{~kg} \text { of } \mathrm{BW} \text { because of reduced feed intake and the appearance of leg problems } \\
\text { n some pigs at BW greater than } 70 \mathrm{~kg} \text {. } \\
{ }^{6} \text { Adjusted least squares means, with ADG during the growing period and } \mathrm{BW} \text { at the beginning of the grow- } \\
\text { ng period as covariates. }\end{array}$} \\
\hline
\end{tabular}

Energy balance data according to pig line and growing period are presented in Table 4 . No line $\times$ period interaction was observed for any of the traits. The ME intake $\left(\mathrm{kJ} \cdot \mathrm{kg}\right.$ of $\left.\mathrm{BW}^{-0.60} \cdot \mathrm{d}^{-1}\right)$ tended to be greater in $\mathrm{RFI}^{+}$pigs than in $\mathrm{RFI}^{-}$pigs. When adjusted for a similar $\mathrm{RE}, \mathrm{ME}$ intake was greater in $\mathrm{RFI}^{+}$pigs $(84 \mathrm{~kJ} \cdot \mathrm{kg}$ of $\left.\mathrm{BW}^{-0.60} \cdot \mathrm{d}^{-1}\right)$. Consequently, $\mathrm{RFI}^{-}$pigs produced $8 \%$ less $\mathrm{HP}$ than $\mathrm{RFI}^{+}$pigs. This reduction was mainly related to a $10 \%$ reduction in FHP (771 vs. $846 \mathrm{~kJ} \cdot \mathrm{kg}$ of $\left.\mathrm{BW}^{-0.60} \cdot \mathrm{d}^{-1} ; P=0.04\right)$ and a tendency for a reduced AHP $\left(-15 \%\right.$ in the RFI ${ }^{-}$line; $\left.P=0.09\right)$. Adjustment of HP or FHP to a constant RE confirmed these observations. The $\mathrm{RE}$ and its partitioning between protein and fat were not affected by the pig line. The RQ values were similar for both lines. In agreement with differences in $\mathrm{HP}$ between the lines, the $\mathrm{CO}_{2}$ production was greater in $\mathrm{RFI}^{+}$pigs than in $\mathrm{RFI}^{-}$pigs. Finally, the overall efficiency of ME utilization [100 - (TEF + AHP)/ME intake] was the same in the 2 lines.

Expressed per unit of metabolic BW, ME intake in P3 was less than in P1 and P2 (-30\%; Table 4). Consequently, RE and HP were 45 and $20 \%$ less in P3 than in the other 2 periods. Neither AHP nor TEF was affected by the experimental period. The decreased ME intake in P3 was associated with decreased RE, both as fat and as protein, because the $\mathrm{RE}_{\mathrm{p}}$ decreased progressively over successive periods $(P<0.001)$, whereas the $\mathrm{RE}_{\mathrm{f}}$ increased, but only between $\mathrm{P} 1$ and $\mathrm{P} 2$. The RQ increased between P1 and P2 in connection with the increased fat retention, and it decreased between
$\mathrm{P} 2$ and P3 in connection with the reduced ME intake. Adjustment of the $\mathrm{CO}_{2}$ production for a constant $\mathrm{RE}$ confirmed the decreased ME intake, and thus RE, during P3. Because ME intake was less during P3, both AHP and TEF, expressed as a percentage of ME intake, were greater during P3. As a consequence of these changes in the components of HP and the utilization of ME between periods, the efficiency of ME for NE was the least $(P<0.001)$ in P3.

Estimates of the $\mathrm{ME}_{\mathrm{m}}$ according to the approach of Kielanowski (1965) were 841 and $920 \mathrm{~kJ} \cdot \mathrm{kg}$ of $\mathrm{BW}^{-0.60} \cdot \mathrm{d}^{-1}$ for $\mathrm{RFI}^{-}$and $\mathrm{RFI}^{+}$pigs, respectively $(P$ $=0.02)$, and the average values for $\mathrm{k}_{\mathrm{p}}$ and $\mathrm{k}_{\mathrm{f}}$ were 0.60 $(1 / 1.68)$ and $0.75(1 / 1.33)$, respectively (equations not shown). These $\mathrm{ME}_{\mathrm{m}}$ values are less than those calculated as $\mathrm{FHP} / \mathrm{k}$ (where $\mathbf{k}$ is the NE:ME ratio; 1,104 and $1008 \mathrm{~kJ} \cdot \mathrm{kg}$ of $\mathrm{BW}^{-0.60} \cdot \mathrm{d}^{-1}$, for $\mathrm{RFI}^{+}$and $\mathrm{RFI}^{-}$, respectively; Table 4).

\section{DISCUSSION}

The present study is part of a larger project to establish new selection criteria and strategies for the sustainable development of pig production. The concept of RFI was first proposed by Koch et al. (1963) in beef cattle. It represents the feed intake in excess of that required for average growth and maintenance requirements (Foster et al., 1983). There are some reports that selection for decreased RFI improves G:F but with a 
Table 3. Effects of line and experimental period on the nutrient and energy digestion, and $\mathrm{N}$ and $\mathrm{P}$ balance in pigs (least squares means; 4 observations per line and per period)

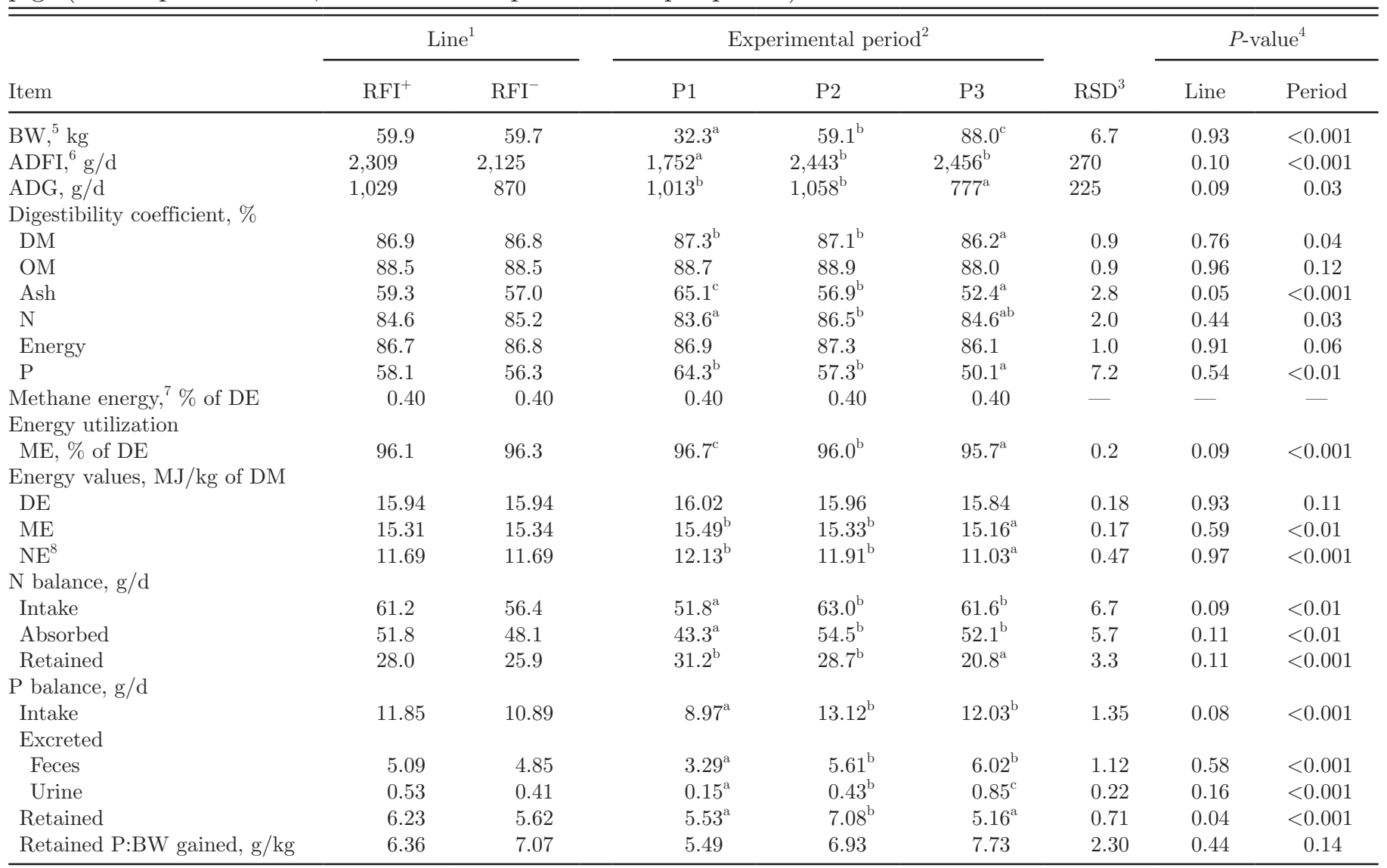

${ }^{\mathrm{a}-\mathrm{C}}$ Within a row, period means without a common superscript differ $(P<0.05)$.

${ }^{1} \mathrm{RFI}^{+}=$high residual feed intake; $\mathrm{RFI}^{-}=$low residual feed intake.

${ }^{2} \mathrm{P} 1=25$ to $45 \mathrm{~kg}$ of BW; $22=45$ to $65 \mathrm{~kg}$ of BW; $33=65$ to $95 \mathrm{~kg}$ of BW.

${ }^{3} \mathrm{RSD}=$ residual $\mathrm{SD}(25 \mathrm{df})$, which is the root mean square of the error that applies to the whole model.

${ }^{4}$ Effects of line or period. The line $\times$ period interaction was not significant for any trait.

${ }^{5} \mathrm{BW}$ in the middle of the balance period.

${ }^{6}$ Adjusted for $87.3 \%$ DM.

${ }^{7}$ The average methane energy loss (\% of DE intake) was used in calculations of ME for all pigs; statistical analysis was not possible.

${ }^{8}$ Calculated as the sum of fasting heat production and retained energy (Noblet et al., 1994); the latter is obtained as the difference between ME and total heat production.

negative correlated effect on growth rate, as described in beef cattle by Hoque et al. (2009). Growth performance data over the growing-finishing period in the current experiment, even though obtained for a small number of animals, confirm those obtained in the selection herd over the successive generations (Gilbert et al., 2007; Sellier et al., 2010) and indicate that selection for decreased RFI can reduce ADFI and improve G:F without adversely affecting the ADG. However, the specific response over the postweaning period with a greater ADG in $\mathrm{RFI}^{+}$pigs should be confirmed with a large number of animals. This will be studied with the data collected in the larger selection experiment that is currently underway. Preliminary calculations on the data collected in the selection farm on the siblings of the pigs used in the present trial and on all the available measurements up to the sixth generation confirm the statistically significant difference between the 2 lines in growth over the postweaning period and $\mathrm{BW}$ at the end of the postweaning period. However, these differences between the 2 lines are approximately one-third of the differences observed in the present trial. This indicates that pigs sampled for the present study would represent extreme differences between the lines in terms of early growth. In any case, these divergent responses among trials for response to selection on RFI are not surprising because the consequences of selection for a feed efficiency trait (e.g., better G:F) on the growth traits (e.g., BW at a given age or ADG) are variable among species, experiments, or response criteria used in the selection program, or all three (Arthur et al., 2001).

Variations in RFI indicate differences in nutrients and energy digestibility, metabolic efficiency of nutrient use, basal metabolic rate and energy expenditure, or all these (Labroue et al., 1999). Digestion of nutrients and energy can be an important source of variation in RFI in ruminants (Richardson and Herd, 2004; Herd and Arthur, 2009), but this seems to be less in laying hens 
to reduced RFI was described by McPhee et al. (2001) in sows and by Lepron et al. (2007) in growing pigs. In both cases, the $\mathrm{RFI}^{-}$pigs were less active and had fewer changes in posture than the $\mathrm{RFI}^{+}$pigs. Finally, it is important to point out that our activity measurements were obtained under specific housing conditions (i.e., metabolism crates). Measurements of activity under conventional housing conditions would be necessary to confirm the results of the current study.

Variation in HP related to an increased TEF between animals differing in RFI has been reported in poultry (Gabarrou et al., 1997). These authors suggested that chickens selected for decreased RFI had less TEF than control line chickens. In ruminants, $\mathrm{O}_{2}$ consumption by the portal-drained viscera (i.e., gastrointestinal tract, pancreas, and spleen) has been positively related to feed intake (Ortigues and Doreau, 1995). In growing pigs, the portal-drained visceral organs account for only $5 \%$ of BW but up to $20 \%$ of total $\mathrm{O}_{2}$ consumption (Yen et al., 1989). Moreover, van Milgen et al. (1998) found that the contribution of viscera (i.e., gastrointestinal tract, liver, pancreas, spleen, kidneys, heart, lungs, bladder, and reproductive organs) to FHP was more than 4 times greater than in lean tissue of growing pigs. It is then possible that selection for decreased RFI and reduced feed intake may decrease the $\mathrm{O}_{2}$ consumption of these organs.

The genetic selection for decreased RFI has been associated with a decreased $\mathrm{ME}_{\mathrm{m}}$ in beef cattle (Herd and Bishop, 2000) and laying hens (Luiting et al., 1991). In contrast, Castro Bulle et al. (2007) did not find differences in $\mathrm{ME}_{\mathrm{m}}$ between lines of beef cattle selected for different RFI. Although little information is available in the literature for growing pigs, our results indicate greater $\mathrm{ME}_{\mathrm{m}}$ values in $\mathrm{RFI}^{+}$pigs, estimated either from the model of Kielanowski (1965) or as FHP/k. The approach of Kielanowski (1965) results in a reduced estimate of $\mathrm{ME}_{\mathrm{m}}\left(841\right.$ and $920 \mathrm{~kJ} \cdot \mathrm{kg}$ of $\mathrm{BW}^{-0.60} \cdot \mathrm{d}^{-1}$ for $\mathrm{RFI}^{-}$and $\mathrm{RFI}^{+}$, respectively) compared with the estimation through $\mathrm{FHP} / \mathrm{k}(1,008$ and $1,104 \mathrm{~kJ} \cdot \mathrm{kg}$ of $\mathrm{BW}^{-0.60} \cdot \mathrm{d}^{-1}$ for $\mathrm{RFI}^{-}$and $\mathrm{RFI}^{+}$, respectively). That difference may be due to the decreased FHP observed in the last experimental period studied [e.g., the model of Kielanowski (1965) assumes a constant $\mathrm{ME}_{\mathrm{m}}$, and thus FHP, for the whole experimental period]. The $\mathrm{ME}_{\mathrm{m}}$ values from the second model used (i.e., FHP/k) are in close agreement with those found in the literature for pigs of different genetic types and sexes (936 to 1,122 $\mathrm{kJ} \cdot \mathrm{kg}$ of $\mathrm{BW}^{-0.60} \cdot \mathrm{d}^{-1}$; Noblet et al., 1999). Preferred estimates for $k_{p}$ and $k_{f}$ values proposed by Noblet et al. (1999) were 0.60 and 0.80 for $\mathrm{k}_{\mathrm{p}}$ and $\mathrm{k}_{\mathrm{f}}$, respectively. The efficiencies in the present experiment $(0.60$ and $0.75)$ are in agreement with those reported by the NRC (1998). Even if our estimates of $k_{p}$ and $k_{f}$ in the present trial are associated with an apparently smaller $\mathrm{ME}_{\mathrm{m}}$ estimation, they are in good agreement with the ranges cited before and they illustrate the multicolinearity of coefficients for protein and lipid retention and $\mathrm{ME}_{\mathrm{m}}$ (Noblet et al., 1999).
The classical estimation of HP proposed by Brouwer (1965) was further developed by the modeling approach of van Milgen et al. (1997), which allows calculation of the different components of HP. Little information is available in the literature concerning the components of energy expenditure or HP in growing pigs, and most of these studies have been carried out in our laboratory (van Milgen et al., 2001; Noblet et al., 2003; Lovatto et al., 2006). Measured values for FHP typically range from 700 to $800 \mathrm{~kJ} \cdot \mathrm{kg}$ of $\mathrm{BW}^{-0.60} \cdot \mathrm{d}^{-1}$, which is consistent with our results (from 669 to $911 \mathrm{~kJ} \cdot \mathrm{kg}$ of $\mathrm{BW}^{-0.60} \cdot \mathrm{d}^{-1}$ for average values per line or per period). The average value of the cost of the physical activity observed in the current study ( $8.7 \%$ of $\mathrm{ME}$ ) is in close agreement with values reported in the literature (i.e., 7.1 to $9.4 \%$ of ME; van Milgen et al., 2001; Noblet et al., 2003; Lovatto et al., 2006). Finally, our estimate of approximately $76 \%$ for the efficiency of ME utilization (NE:ME) is consistent with the value of $75 \%$ reported in the literature (Noblet et al., 1994, 2001; Le Bellego et al., 2001). In contrast, the differences observed in the present experiment for this variable in both growth periods and lines may be related to different distributions of TEF and activity during the day, and thus to variation in the dynamics of HP.

In the present study, important physiological processes (e.g., feed intake, $\mathrm{HP}$ and its partitioning, and $\mathrm{ME}_{\mathrm{m}}$ ) have been studied and discussed in relation to RFI. However, little information is available in the literature on the relationship between these traits and specific biological pathways (Herd and Arthur, 2009). In recent years, some biochemical, molecular, and genomic studies have been developed to understand the mechanisms contributing to the basis for variation in RFI in beef cattle or poultry (Hill and Azain, 2009). The energy production (i.e., ATP) in mitochondria has an essential role in whole-body metabolic processes. Thus, it is expected that an altered mitochondrial function may modify the feed efficiency. Differences in mitochondrial membrane potential in poultry (Ojano-Dirain et al., 2007) or in mitochondrial respiration in steers (Kolath et al., 2006) have been reported. However, to our knowledge, no comparable information is available concerning growing pigs, and unfortunately, these biochemical and molecular variables were not measured in the current study.

In conclusion, this study indicates that a substantial genetic change in the dynamics of energy partitioning in the growing animal has occurred in 2 divergent lines of Large White pigs selected to differ in RFI. Pigs from the $\mathrm{RFI}^{+}$line exhibited a greater HP than those from the $\mathrm{RFI}^{-}$line. This difference was mainly due to a greater basal metabolic rate and, to a lesser extent, to increased physical activity. Energy retention and its partitioning between protein and fat did not differ between the 2 lines. Further research is required to better understand the behavioral, physiological, biochemical, molecular, and genomic mechanisms responsible for variation in RFI in pigs. 


\section{LITERATURE CITED}

AOAC. 1990. Official Methods of Analysis. 15th ed. Assoc. Off. Anal. Chem., Gaithersburg, MD.

Arthur, P. F., J. A. Archer, D. J. Johnston, R. M. Herd, E. C. Richardson, and P. F. Parnell. 2001. Genetic and phenotypic variance and covariance components for feed intake, feed efficiency, and other postweaning traits in Angus cattle. J. Anim. Sci. 79:2805-2811.

Bordas, A., and P. Mérat. 1981. Genetic variation and phenotypic correlations of food consumption of laying hens corrected for body weight and production. Br. Poult. Sci. 22:25-33.

Brouwer, E. 1965. Report of subcommittee on constants and factors. Pages 441-443 in Energy Metabolism. Proc. 3rd Symp. Eur. Assoc. Anim. Prod., Troon, UK. Acad. Press, London, UK.

Cai, W., D. S. Casey, and J. C. M. Dekkers. 2008. Selection response and genetic parameters for residual feed intake in Yorkshire swine. J. Anim. Sci. 86:287-298.

Carré, B., S. Mignon-Grasteau, and H. Juin. 2008. Breeding for feed efficiency and adaptation to feed in poultry. World's Poult. Sci. J. $64: 377-390$

Castro Bulle, F. C., P. V. Paulino, A. C. Sanches, and R. D. Sainz. 2007. Growth, carcass quality, and protein and energy metabolism in beef cattle with different growth potentials and residual feed intakes. J. Anim. Sci. 85:928-936.

de Haer, L. C. M., P. Luiting, and H. L. M. Aarts. 1993. Relations among individual (residual) feed intake, growth performance and feed intake pattern of growing pigs in group housing. Livest. Prod. Sci. 36:233-253.

de Lange, K., J. van Milgen, J. Noblet, S. Dubois, and S. Birkett. 2006. Previous feeding level influences plateau heat production following a $24 \mathrm{~h}$ fast in growing pigs. Br. J. Nutr. 95:10821087.

European Economic Community. 1972. Analytical determination of starch. Page 7 in Off. J. Eur. Communities Publ. No. 123. Eur. Econ. Community, Brussels, Belgium.

Foster, W. H., D. J. Kilpatrick, and I. H. Heaney. 1983. Genetic variation in the efficiency of energy utilization by the fattening pig. Anim. Prod. 37:387-393.

Gabarrou, J. F., P. A. Geraert, M. Picard, and A. Bordas. 1997. Diet-induced thermogenesis in cockerels is modulated by genetic selection for high or low residual feed intake. J. Nutr. 127:2371-2376.

Gabarrou, J. F., P. A. Geraert, J. Williams, L. Ruffier, and N. Rideau. 2000. Glucose-insulin relationships and thyroid status of cockerels selected for high or low residual food consumption. Br. J. Nutr. 83:645-651.

Gilbert, H., S. Al Aïn, J.-P. Bidanel, H. Lagant, Y. Billon, P. Guillouet, J. Noblet, and P. Sellier. 2009. Sélection divergente sur la consommation alimentaire résiduelle du porc en croissance: Effets corrélatifs sur le comportement alimentaire. J. Rech. Porcine Fr. 41:149-150.

Gilbert, H., J.-P. Bidanel, J. Gruand, J.-C. Caritez, Y. Billon, P. Guillouet, H. Lagant, J. Noblet, and P. Sellier. 2007. Genetic parameters for residual feed intake in growing pigs, with emphasis on genetic relationships with carcass and meat quality traits. J. Anim. Sci. 85:3182-3188.

Grima, L., E. Quillet, T. Boujard, C. Robert-Granié, B. Chatain, and M. Mambrini. 2008. Genetic variability in residual feed intake in rainbow trout clones and testing of indirect selection criteria. Genet. Sel. Evol. 40:607-624.

Henry, Y. 1993. Affinement du concept de la protéine idéale pour le porc. INRA Prod. Anim. 6:199-212.

Herd, R. M., and P. F. Arthur. 2009. Physiological basis for residual feed intake. J. Anim. Sci. 87(E-Suppl.):E64-E71.

Herd, R. M., and S. C. Bishop. 2000. Genetic variation in residual feed intake and its association with other production traits in British Hereford cattle. Livest. Prod. Sci. 63:111-119.

Hill, R. A., and M. Azain. 2009. Growth and development symposium: The molecular basis for feed efficiency. J. Anim. Sci. 87(E-Suppl.):E39-E40.
Hoque, M. A., M. Hosono, and K. Suzuki. 2009. Genetic parameters for dry matter, energy and protein intake, and their relationships with performance and carcass traits in Japanese Black cattle. J. Anim. Breed. Genet. 126:14-21.

Kielanowski, J. 1965. Estimates of the energy cost of protein deposition in growing animals. Pages $13-20$ in Proc. 3rd Symp. Energy Metabolism. K. L. Blaxter, ed. Academic Press, London, U.K.

Koch, R. M., L. A. Swiger, D. Chambers, and K. E. Gregory. 1963. Efficiency of feed use in beef cattle. J. Anim. Sci. 22:486494.

Kolath, W. H., M. S. Kerley, J. W. Golden, and D. H. Keisler. 2006. The relationship between mitochondrial function and residual feed intake in Angus steers. J. Anim. Sci. 84:861-865.

Labroue, F., L. Maignel, P. Sellier, and J. Noblet. 1999. Consommation résiduelle chez le porc en croissance alimenté à volonté. J. Rech. Porcine Fr. 31:167-174.

Le Bellego, L., J. van Milgen, S. Dubois, and J. Noblet. 2001. Energy utilization of low protein diets in growing pigs. J. Anim. Sci. 79:1259-1271.

Lepron, E., R. Bergeron, S. Robert, L. Faucitano, J. F. Bernier, and C. Pomar. 2007. Relationship between residual energy intake and the behaviour of growing pigs from three genetic lines. Livest. Sci. 111:104-113.

Lovatto, P. A., D. Sauvant, J. Noblet, S. Dubois, and J. van Milgen. 2006. Effects of feed restriction and subsequent refeeding on energy utilization in growing pigs. J. Anim. Sci. 84:3329-3336.

Luiting, P., J. W. Schrama, W. van der Hel, and E. M. Urff. 1991. Metabolic differences between White Leghorns selected for high and low residual food consumption. Br. Poult. Sci. 32:763782.

Luiting, P., and E. M. Urff. 1991. Residual feed consumption in laying hens. 2. Genetic variation and correlations. Poult. Sci. 70:1663-1672.

Luiting, P., E. M. Urff, and M. W. A. Verstegen. 1994. Betweenanimal variation in biological efficiency as related to residual feed consumption. Neth. J. Agric. Sci. 42:59-67.

McPhee, C. P., J. C. Kerr, and N. D. Cameron. 2001. Peri-partum posture and behaviour of gilts and the location of their piglets in lines selected for components of efficient lean growth. Appl. Anim. Behav. Sci. 71:1-12.

Nguyen, N. H., C. P. McPhee, and C. M. Wade. 2005. Responses in residual feed intake in lines of Large White pigs selected for growth rate on restricted feeding (measured on ad libitum individual feeding). J. Anim. Breed. Genet. 122:264-270.

Nkrumah, J. D., D. H. Crews Jr., J. A. Basarab, M. A. Price, E. K. Okine, Z. Wang, C. Li, and S. S. Moore. 2007. Genetic and phenotypic relationships of feeding behavior and temperament with performance, feed efficiency, ultrasound, and carcass merit of beef cattle. J. Anim. Sci. 85:2382-2390.

Nkrumah, J. D., E. K. Okine, G. W. Mathison, K. Schmid, C. Li, J. A. Basarab, M. A. Price, Z. Wang, and S. S. Moore. 2006. Relationships of feedlot feed efficiency, performance, and feeding behavior with metabolic rate, methane production, and energy partitioning in beef cattle. J. Anim. Sci. 84:145-153.

Noblet, J., H. Fortune, X. S. Shi, and S. Dubois. 1994. Prediction of net energy value of feeds for growing pigs. J. Anim. Sci. $72: 344-354$

Noblet, J., Y. Henry, and S. Dubois. 1987. Effect of protein and lysine levels in the diet on body gain composition and energy utilization in growing pigs. J. Anim. Sci. 65:717-726.

Noblet, J., C. Karege, S. Dubois, and J. van Milgen. 1999. Metabolic utilization of energy and maintenance requirements in growing pigs: Effects of sex and genotype. J. Anim. Sci. 77:12081216.

Noblet, J., L. Le Bellego, J. van Milgen, and S. Dubois. 2001. Effects of reduced dietary protein level and fat addition on heat production and nitrogen and energy balance in growing pigs. Anim. Res. 50:227-238.

Noblet, J., J. van Milgen, B. Carré, P. Dimon, S. Dubois, M. Rademacher, and S. van Cauwenberghe. 2003. Effect of body 
weight and reduction of dietary crude protein on energy utilisation in growing pigs and broilers. Pages 205-209 in Progress in Research on Energy and Protein Metabolism. Eur. Assoc. Anim. Prod. Publ. 109. W. B. Souffrant and C. C. Metges, ed. Wageningen Academic Publishers, Wageningen, the Netherlands.

NRC. 1998. Nutrient Requirements of Swine. 10th rev. ed. Natl. Acad. Press, Washington, DC.

Ojano-Dirain, C. P., N. R. Pumford, M. Toyomizu, and W. G. Bottje. 2007. Association of mitochondrial function and feed efficiency. Jpn. Poult. Sci. 44:221-237.

Ortigues, I., and M. Doreau. 1995. Responses of the splanchnic tissues of ruminants to changes in intake: Absorption of digestion end products, tissue mass, metabolic activity and implications to whole animal energy metabolism. Ann. Zootech. 44:321346.

Patterson, H. D., and R. Thompson. 1971. Recovery of interblock information when block sizes are unequal. Biometrika 58:545554 .

Richardson, E. C., and R. M. Herd. 2004. Biological basis for variation in residual feed intake in beef cattle. 2. Synthesis of results following divergent selection. Aust. J. Exp. Agric. 44:431440.

Sauvant, D., J. M. Perez, and G. Tran. 2004. Tables of composition and nutritional value of feed materials. Pigs, poultry, cattle, sheep, goats, rabbits, horses, fish. INRA Editions and AFZ, Paris, France.

Sellier, P., Y. Billon, J. Riquet, H. Lagant, J. A. Calderon, P. Guillouet, J. P. Bidanel, J. Noblet, and H. Gilbert. 2010. Six générations de sélection divergente pour la consommation journalière résiduelle chez le porc en croissance: Réponses corrélatives sur les caractères de reproduction des truies et synthèse des réponses sur les caractéristiques de production. J. Rech. Porcine Fr. 42:167-172.
Sève, B., and N. Le Floc'h. 1998. Valorisation mutuelle du L-tryptophane et de la L-thréonine supplémentaires dans l'aliment deuxième âge du porcelet. Rôle de la thréonine déshydrogénase hépatique. J. Rech. Porcine Fr. 30:209-216.

Silverstein, J. T., M. Hostuttler, and K. P. Blemings. 2005. Strain differences in feed efficiency measured as residual feed intake in individually reared rainbow trout, Oncorhynchus mykiss (Walbaum). Aquacult. Res. 36:704-711.

van Milgen, J., J. F. Bernier, Y. Lecozler, S. Dubois, and J. Noblet. 1998. Major determinants of fasting heat production and energetic cost of activity in growing pigs of different body weight and breed/castration combination. Br. J. Nutr. 79:509-517.

van Milgen, J., and J. Noblet. 2003. Partitioning of energy intake to heat, protein, and fat in growing pigs. J. Anim. Sci. 81(ESuppl.):E86-E93.

van Milgen, J., J. Noblet, and S. Dubois. 2001. Energetic efficiency of starch, protein, and lipid utilization in growing pigs. J. Nutr. 131:1309-1318.

van Milgen, J., J. Noblet, S. Dubois, and J. F. Bernier. 1997. Dynamic aspects of oxygen consumption and carbon dioxide production in swine. Br. J. Nutr. 78:397-410.

Van Soest, P. J., and R. H. Wine. 1967. Use of detergents in the analysis of fibrous feeds. IV. Determination of plant cell-wall constituents. J. Assoc. Off. Agric. Chem. 50:50-55.

Vermorel, M., J.-C. Bouvier, Y. Bonnet, and G. Fauconneau. 1973. Construction et fonctionnement de 2 chambres respiratoires du type "circuit ouvert" pour jeunes bovins. Ann. Biol. Anim. Biochim. Biophys. 13:659-681.

Yen, J. T., J. A. Nienaber, D. A. Hill, and W. G. Pond. 1989. Oxygen consumption by portal vein-drained organs and by whole animal in conscious growing swine. Proc. Soc. Exp. Biol. Med. 190:393-398. 